\title{
Diseases of Peanut Caused by Soilborne Pathogens in the Southwestern United States
}

\author{
Lindsey D. Thiessen ${ }^{1}$ and Jason E. Woodward ${ }^{1,2}$ \\ ${ }^{1}$ Department of Plant and Soil Science, Texas Tech University, Lubbock, TX 79409, USA \\ ${ }^{2}$ Texas AgriLife Extension Service, Texas A\&M System, Lubbock, TX 79403, USA \\ Correspondence should be addressed to Jason E. Woodward, jewoodward@ag.tamu.edu
}

Received 25 June 2012; Accepted 19 July 2012

Academic Editors: K. Jaggard and W. P. Williams

Copyright ( $\odot 2012$ L. D. Thiessen and J. E. Woodward. This is an open access article distributed under the Creative Commons Attribution License, which permits unrestricted use, distribution, and reproduction in any medium, provided the original work is properly cited.

Peanut (Arachis hypogaea L.) is susceptible to diseases caused by numerous soilborne pathogens. In the southwestern United States pathogens including Botrytis cinerea Pers.: Fr., Pythium spp., Rhizoctonia solani Kühn AG-4, Sclerotinia minor Jagger and Sclerotinia sclerotiorum (Lib.) de Bary, Sclerotium rolfsii Sacc., and Verticillium dahliae Kleb. routinely affect peanut yield. This region has an arid climate and peanut development is generally later than in other peanut production areas, hence the time plants are exposed to pathogens is increased. These pathogens cause similar symptoms in the field; therefore, proper diagnosis is needed so that the appropriate management strategies can be implemented.

\section{Introduction}

Peanut (Arachis hypogaea L.) is an important food and oilseed crop worldwide. Peanut plants are approximately $15-$ $60 \mathrm{~cm}$ tall and produce pinnate leaves with two opposing pairs of leaflets $2-5 \mathrm{~cm}$ long [1]. The plant produces yellow flowers that form on nonvegetative branches and withers within 5 to 6 hours after opening [2]. Following pollination the flower produces a peg, at the apex of which pod production occurs. The mature pod is an indehiscent legume that may contain 1-5 seeds [2].

Arachis species are native to South America, originating in central Brazil, and sixty-nine species have been discovered [3]. Arachis hypogaea is cultivated worldwide, with the United States being the world's third largest producer. Peanut production in the United States is concentrated in the southeast and portions of the southwest. In the southwest, peanut production is concentrated in Texas, Oklahoma, and New Mexico, with Texas being the second largest peanut producing state in the United States, producing nearly 180 million kilograms in 2010 [4].

Diseases pose a major threat to the production of peanuts each year, and prevention of disease in peanut is a major concern for producers. Diseases caused by soilborne pathogens especially pose a threat to peanut production due to the similarity of symptoms, which leads to problems in diagnosis. In addition to direct losses, the management of soilborne diseases results in increased input costs.

Peanut is susceptible to losses incited by soilborne pathogens due to the close association of the pods with the soil. Soilborne diseases are especially complicated to manage due to the difficulty of dispersing fungicides through the peanut canopy to the soil profile. Several soilborne pathogens that affect peanut are important to the Southwest United States, including Botrytis cinerea, Pythium spp., Rhizoctonia solani, Sclerotinia minor and S. sclerotiorum, Sclerotium rolfsii, and Verticillium dahliae.

\section{Botrytis cinerea}

Botrytis blight, also known as gray mold (Figure 1), of peanut occurs only sporadically as conducive conditions consisting of cool and wet weather are often not present during the growing season in the Southwest United States. Botrytis cinerea Pers.: Fr. (anamorph) is a Deuteromycete that colonizes the plant quickly. Botryotinia fuckeliana (teleomorph) is an Ascomycete, which is rarely seen. The fungus may cause the wilt and death of plant tissue or the entire plant. All parts 


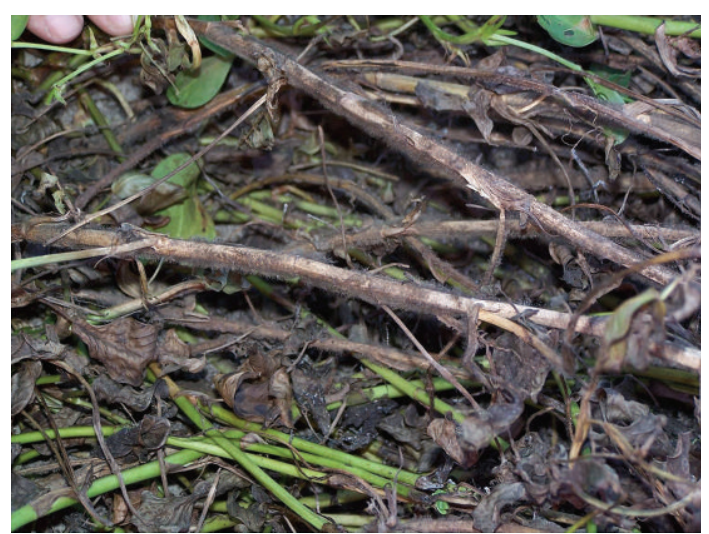

Figure 1: Botrytis cinerea affecting peanut at the base of the host plant.

of the peanut plant are susceptible to this fungus, especially when in contact with the soil. Plants are particularly susceptible when injured by frost damage or other pathogens.

In culture, $B$. cinerea produces darkly pigmented, aerial mycelia and irregularly shaped black sclerotia (Figure 2). Conidia of the fungus are 9-12 $\times 6.5-10 \mu \mathrm{m}$ and ellipsoid to ovoid, pigmented, and single-celled (Figure 2) [5]. These conidia are produced abundantly in a botryoid habit on the ends of conidiophores, which cause the lesions to appear gray and moldy. The fungus overwinters as large sclerotia, which are typically dark-brown to black and irregularly shaped, and are formed by coalescing hyphae. This fungus prefers temperatures below $20^{\circ} \mathrm{C}$ and high humid conditions for colonization [5].

\section{Pythium species}

Several Pythium spp. have been found in association with diseased peanuts, and have been implicated in the pod rot complex (Figure 3). In a survey by Wheeler et al. in 2005, approximately $40 \%$ of fields in West Texas were found to contain Pythium spp., primarily P. myriotylum, P. irregulare, and $P$. ultimum, which are capable of causing damage to the pod and the kernels and may cause significant yield loss [6]. Pythium spp. may also cause damping off, vascular wilt, and root rot of peanut. Yield losses caused by Pythium pod rot are difficult to accurately determine due to the lack of aboveground symptoms, but losses as high as $80 \%$ have been reported [7]. Pod rot caused by Pythium spp. may also cause the junction of the peg and pod to become weakened, which may result in substantial loss at harvest [8].

Pythium spp. are oomycetes, also known as water molds, with motile zoospores capable of chemotaxis in films of water. Upon reaching a host, the zoospores germinate, producing hyaline, coenocytic hyphae that cause infection of plant tissue. Pythium spp. is characterized by white, fluffy mycelia (Figure 4) that produces asexual reproductive structures, sporangia. Sporangia may germinate by producing a germ tube or zoospores. During the sexual cycle, oospores are created by the mating of the oogonium and antheridium,

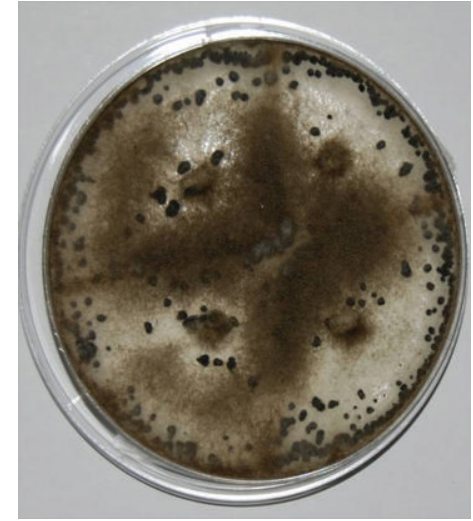

(a)

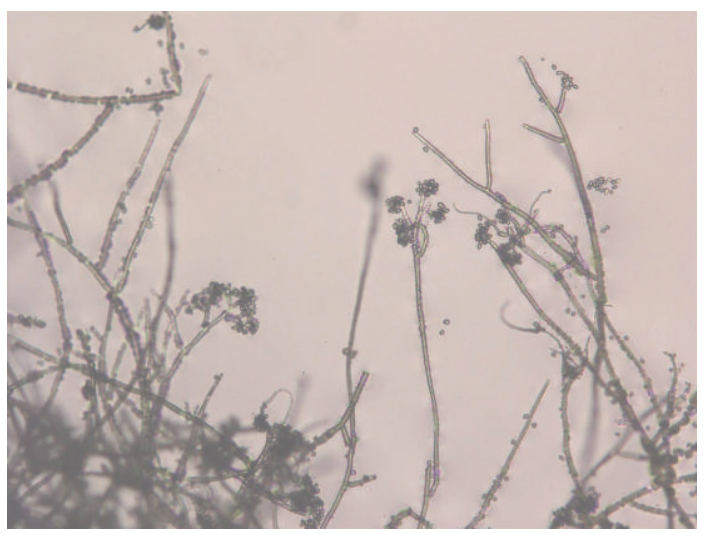

(b)

FIgURe 2: Cultural (a) and morphological (b) characteristics of Botrytis cinerea, causal agent of Botrytis blight.

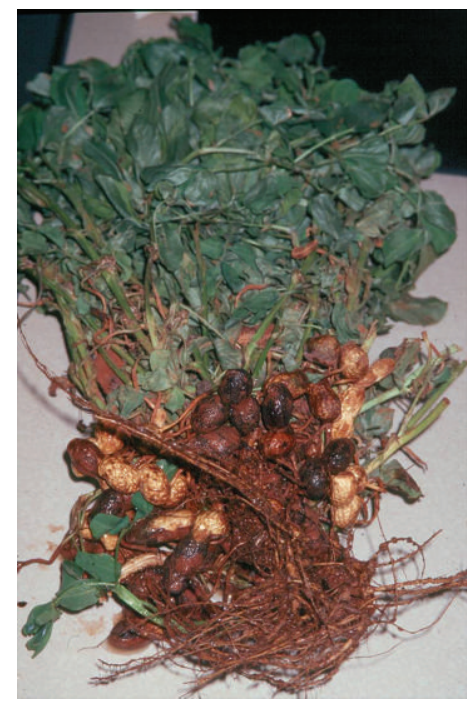

Figure 3: Pod rot of peanut caused by Pythium spp., which causes a black, water-soaked appearance of the peanut hull. (photo courtesy of Wheeler, Texas AgriLife Research). 


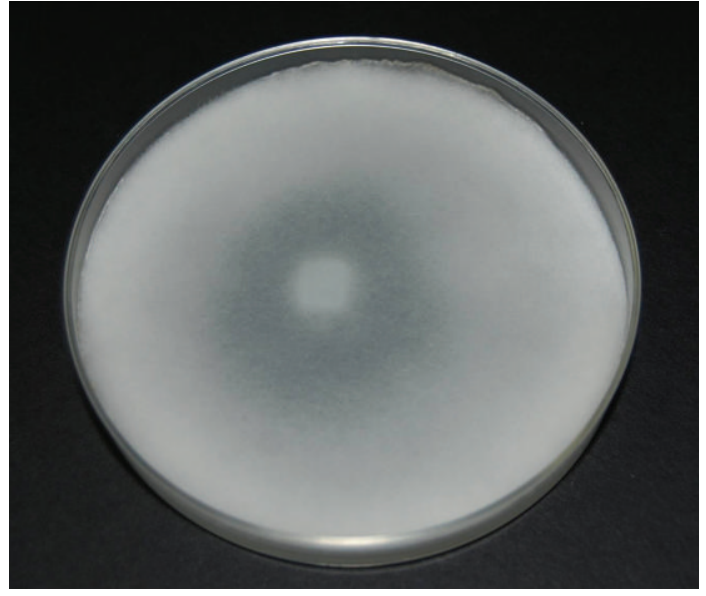

Figure 4: Culture of Pythium myriotylum on potato dextrose agar; characterized by white, fluffy mycelium.

and produce a germ tube that is capable of penetrating new tissue [7]. Oospores also serve as the primary survival structures for Pythium spp.

In preemergence or postemergence damping off, the roots rapidly decay and the top of the plant collapses. Peanut plants exhibiting root rot are generally stunted and may overcome the disease under favorable growing conditions [7]. Pythium pod rot is characterized by the browning and water-soaking of pods followed by a brown to black appearance in the final stages of rot. The pegs may also begin to decay, and at harvest, blackened remains of pegs are all that is left at harvest [9]. Symptoms of Pythium pod rot are most severe when there are frequent rains or excessive irrigation during pod development allowing for the ability of zoospores to move through water.

\section{Rhizoctonia solani}

Seed decay, damping-off, root rot, limb rot, and pod rot may all be caused by Rhizoctonia solani. When conditions are unfavorable for seedling development, diseases caused by $R$. solani may become serious and reduce yields. Rhizoctonia solani is a ubiquitous fungus with a wide host range that may be difficult to differentiate from other seed decaying pathogens, making the management of $R$. solani diseases difficult. Assessing the losses caused by $R$. solani is also difficult to ascertain because pod rot may be caused by various soilborne pathogens and displays no above ground symptoms.

Rhizoctonia solani Kühn (anamorph) is a Deuteromycete that does not produce asexual spores; the teleomorph, Thanatephorus cucumeris, is a Basidiomycete. The hyphae of $R$. solani are pigmented (Figure 6) and septate, and display $90^{\circ}$ hyphal branching. The fungus also produces nondifferentiated sclerotia that survive on plant debris. Rhizoctonia solani is capable of surviving saprophytically on a wide host range, including rotated crops and various weed species [10]. Host tissue may be infected by germinating sclerotia or hyphae in the soil or on plant debris. Hyphae penetrate new tissue through appressoria or through wounds and natural openings of the plant. Various anastamosis groups (AG) of Rhizoctonia spp. occur; however, AG-4 is the most common cause of limb rot and pod rot in peanut [11].

Rhizoctonia solani may infect plants at any stage of development and may cause seed decay prior to emergence. On emerged seedlings, dark, sunken lesions just below the soil line become present and under favorable disease conditions, the fungus will cause plant death. Rhizoctonia limb rot is characterized by dark brown target-patterned lesions on stems and lower branches in contact with the soil line [10, 12]. Rhizoctonia pod rot is differentiated by a dry, brown or russet-colored rotted pod (Figure 5), as opposed to the dark, greasy-appearing lesions as characterized by Pythium spp. Peanut seed may become infected and will harbor the fungus after drying and storing [9].

\section{Sclerotinia minor and Sclerotinia sclerotiorum}

Sclerotinia blight is caused by Sclerotinia minor Jagger, and on rare occasions may be caused by Sclerotinia sclerotiorum (Lib.) de Bary [13-15]. Yield losses caused by Sclerotinia blight are commonly $10 \%$, but may often exceed $50 \%$ in severe cases $[13,16]$.

Sclerotinia minor and S. sclerotiorum are ascomycetes that produce white aerial mycelia and black, irregularly shaped sclerotia. The sclerotia of $S$. minor are often small and abundantly produced (Figure 8 ), whereas the sclerotia of $S$. sclerotiorum are large and less abundant (Figure 8 ), which may be easily confused with the sclerotia produced by $B$. cinerea. The apothecia produced by $S$. minor are rarely seen during the growing season and are produced more readily by $S$. sclerotiorum in other crops. One sclerotium may give rise to one or several apothecia that are pale orange to white [13]. The ascospores produced in the asci range from $8-17 \times 5-$ $7 \mu \mathrm{m}[13]$.

Sclerotinia minor overwinters as sclerotia, and under favorable environmental conditions, the sclerotia germinate myceliogenically. Plant tissue in contact with soil infested with S. minor becomes infected. Infected plants rapidly wilt and show chlorotic, water-soaked lesions near the soil line. As the disease progresses, white fluffy mycelia develops on the surface of affected tissue. The fungus eventually causes branches to become chlorotic then turn dark brown (Figure 7). The branches begin to have a shredded appearance due to oxalic acid produced by $S$. minor. As infected tissues degrades, sclerotia are produced and shed into the soil, where they overwinter until optimum conditions exist to germinate myceliogenically or carpogenically.

\section{Sclerotium rolfsii}

Southern blight, also known as white mold, southern stem rot, and Sclerotium rot, is caused by the fungus Sclerotium rolfsii Sacc. The fungus is ubiquitous and has a wide host range [17-19]. This disease is found in all major peanutgrowing areas of the world [17], but is most common in the 


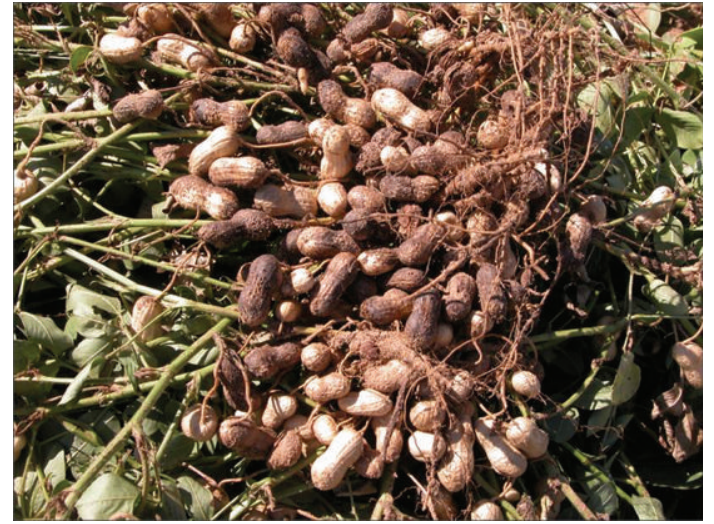

Figure 5: Rhizoctonia solani infected pods, which cause a dry, russet-brown rot.

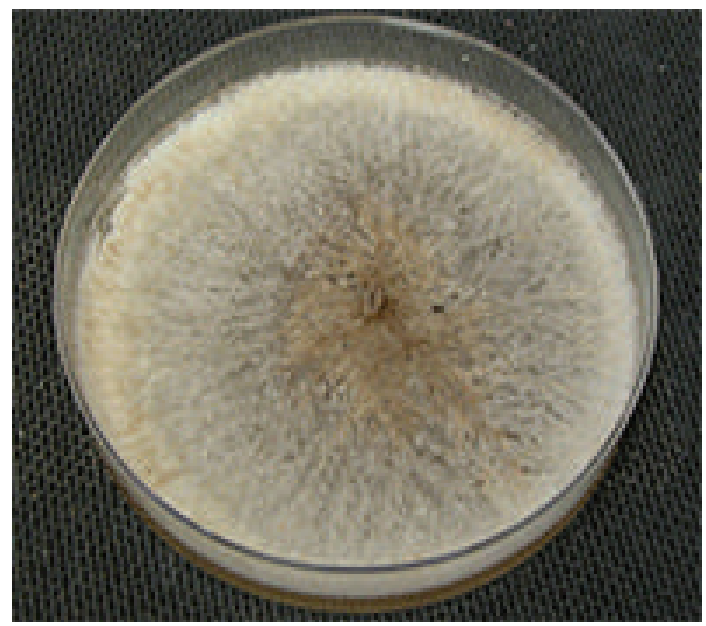

FIGURE 6: Culture of Rhizoctonia solani on potato dextrose agar, which is characterized by pigmented hyphae, and the production of sclerotia.

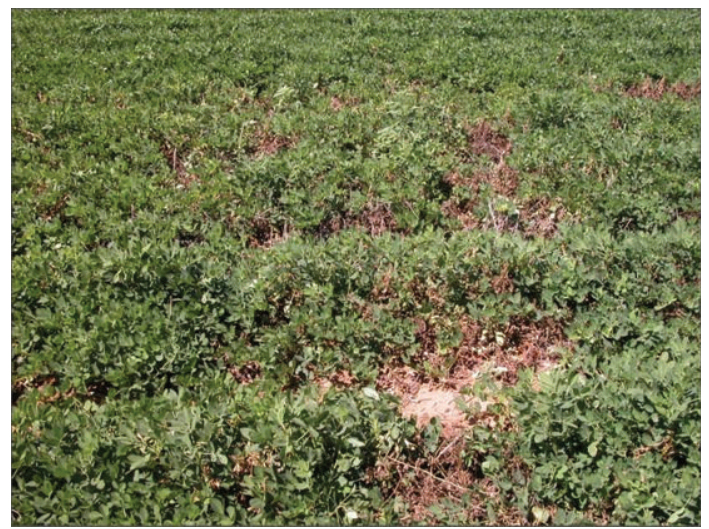

Figure 7: Symptoms of Sclerotinia blight, caused by Sclerotinia minor or S. sclerotiorum, generally occur as patches throughout the field.

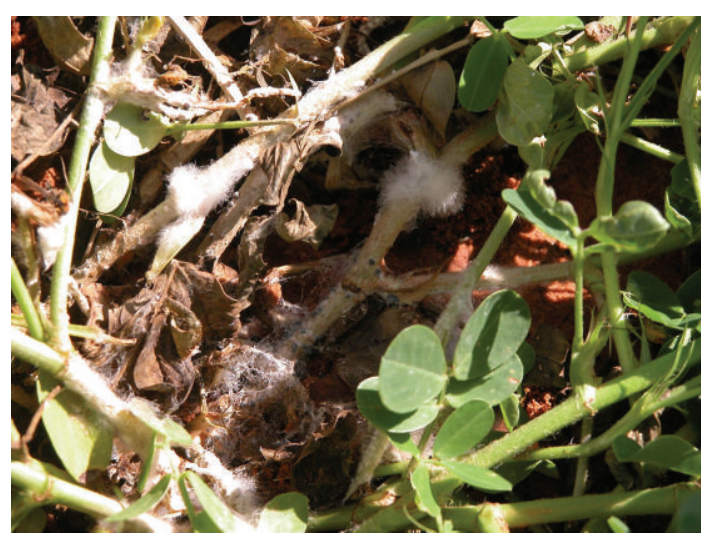

(a)

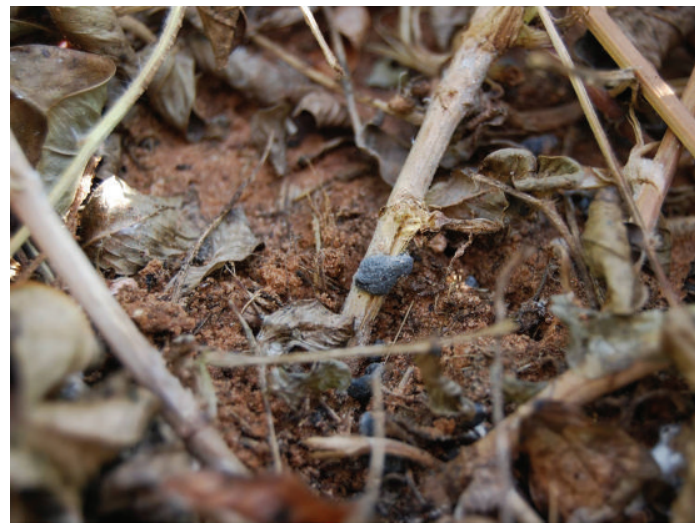

(b)

FIGURE 8: White mycelial growth and small, black, irregular sclerotia of Sclerotinia minor (a) and large, black sclerotia of $S$. sclerotiorum (b).

southern United States, where high temperatures support the growth of the fungus [19]. In extreme cases, the disease may cause up to $80 \%$ yield loss; however, losses less than $25 \%$ are more typical [17].

Sclerotium rolfsii does not produce conidia and is a Deuteromycete, in the group "Mycelia Sterilia." Although a sexual stage of S. rolfsii, Athelia rolfsii (Cruz) Tu \& Kimbrough, has been identified, it is rarely seen in either the field or under laboratory conditions and does not appear to play a role in the disease cycle $[17,20]$. Sclerotium rolfsii has a host range of more than 200 plant species and may colonize living or dead plant tissue. The fungus is characterized by white mycelia, and round, brown sclerotia, which range from 0.5$2 \mathrm{~mm}$ in diameter (Figure 9) [19]. The mycelia of S. rolfsii survives best in sandy soils, whereas the sclerotia survive best in moist, aerobic conditions found at the soil surface [19].

Initial symptoms of Southern blight include a yellowing and wilting of the main stem, the lateral branches, or entire plant. White mycelium may be observed at the base of the plant near the soil line. Under favorable conditions, warm temperatures and high humidity, during the growing season, the mycelia rapidly spread to other branches and peanut plants. These sclerotia are spherical and are initially white, 


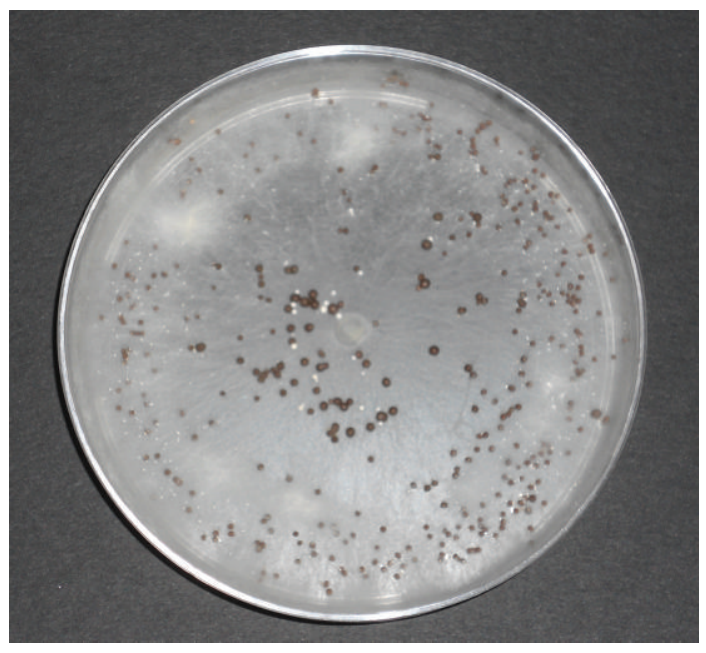

FIGURE 9: Culture of Sclerotium rolfsii on potato dextrose agar. Note the fungus produces white aerial mycelium with round, brown sclerotia.

but later become light brown to dark brown in color and serve as the initial inoculum [17]. Temperature fluctuations, fungal isolate, and nutrient availability may affect sclerotial formation size and shape (Figure 10) [19].

If the pathogen infects the pods, the pods exhibit a brown rot with a water-soaked and mashed appearance (Figure 11) [19]. This may occur with the plant displaying no aboveground symptoms. Often, when infected pods are removed from the ground, the mycelium covered pods show soil adhering to the fungal hyphae.

\section{Verticillium dahliae}

Verticillium wilt of peanut is caused by Verticillium dahliae Kleb. Verticillium dahliae is capable of surviving in the soil for long periods of time as microsclerotia. This makes management through crop rotation difficult in the Southern High Plains because the other crops (primarily cotton, Gossypium hirsutum L.) rotated in this region are also susceptible to infection by $V$. dahliae. Yield losses may become severe in heavily infested fields (Figure 12).

Verticillium dahliae grows most abundantly at $32^{\circ} \mathrm{C}$ and forms microsclerotia $(50-200 \mu \mathrm{m})$ as overwintering structures [21]. The fungus produces white fluffy mycelia and conidia $(3 \times 6.5 \mu \mathrm{m})$ that are hyaline and single-cellular [21]. These conidia may be borne singly or in clusters. As a monocyclic disease, the density of initial inoculum in the soil may determine the severity of the disease in the field [22]. Microsclerotia develop on plant debris and are capable of surviving environmental stresses for extended periods of time, often for several years. Dormant microsclerotia germinate when stimulated by root exudates. The fungus enters the roots of the host plant and expands through the vascular system of the plant. Conidia produced on conidiophores may quickly spread through the xylem and systemically infect the host plant. Infection of the vascular system causes marginal leaf chlorosis and necrosis as well as loss of turgidity of the plant (Figure 13). Wilting, defoliation,

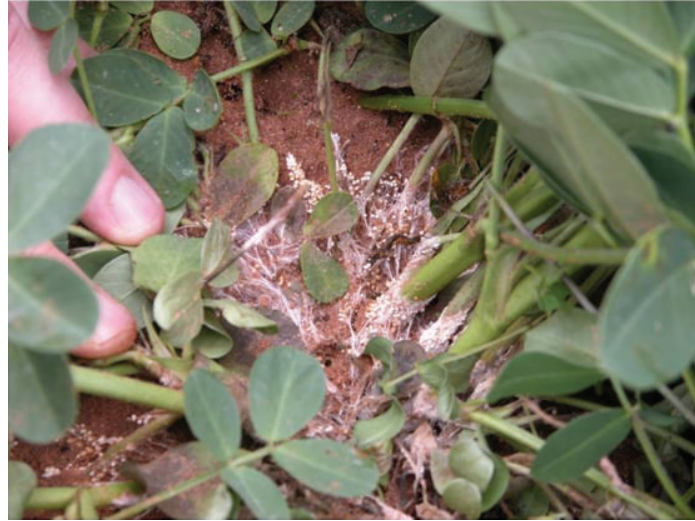

Figure 10: White mycelial growth of Sclerotium rolfsii on crown of peanut plant with sclerotia forming on infected tissue.

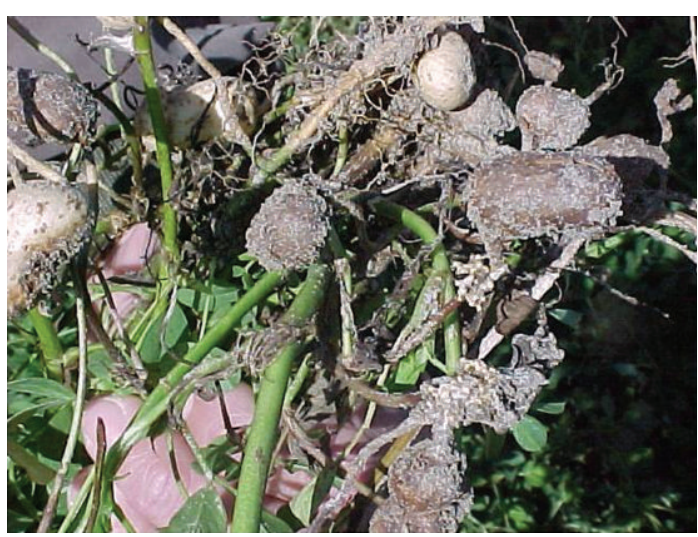

FIGURE 11: Sclerotium rolfsii affecting the pods of a peanut plant, causing pod decay. (photo courtesy of Kemerait, Jr., University of Georgia).

and general yellowing of the plants may also be observed in affected plants. Internally, vascular discoloration occurs in the roots and petioles of the leaves (Figure 13).

\section{Cultural Management Practices}

Management of soilborne pathogens of peanut is most effective when cultural practices are utilized in concert with chemical control methods. Many cultural practices focus on reducing soil inoculum that come into contact with the host plant. Deep tillage will often reduce soil inoculum by burying the pathogen within the soil to impose anaerobic conditions [19]; however, due to the environmental conditions, this region utilizes conservation tillage practices, and deep tillage may not be an option for many growers. Utilizing cultivation methods that do not pitch soil onto the crowns of peanut plants reduces disease by limiting the contact of soil inoculum with the plant [19]. Also, cultivation methods that limit injury to peanut plants will limit access of pathogens to the plants through wounds in the plant tissue. Using clean seed treated with preventative chemical treatments will reduce the introduction of new inoculum to the field. In addition to limiting soil inoculum contact, factors such as 


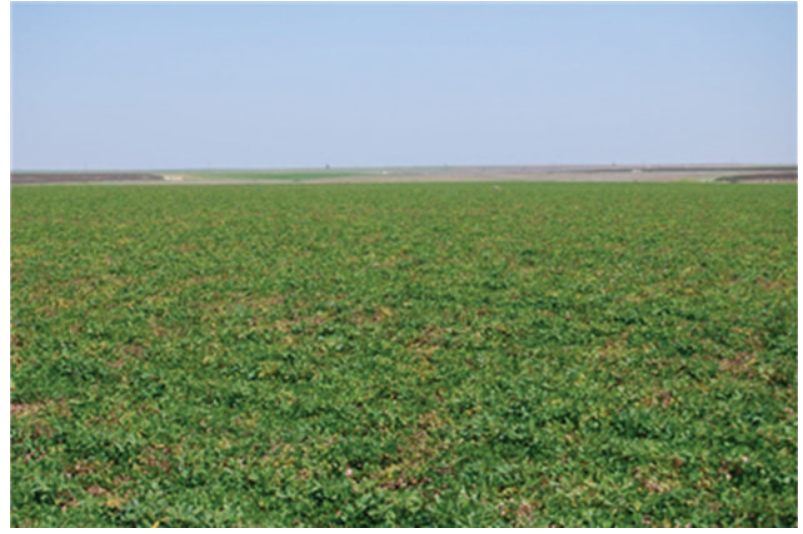

FIGURE 12: Patches of wilted plants affected by Verticillium dahliae.

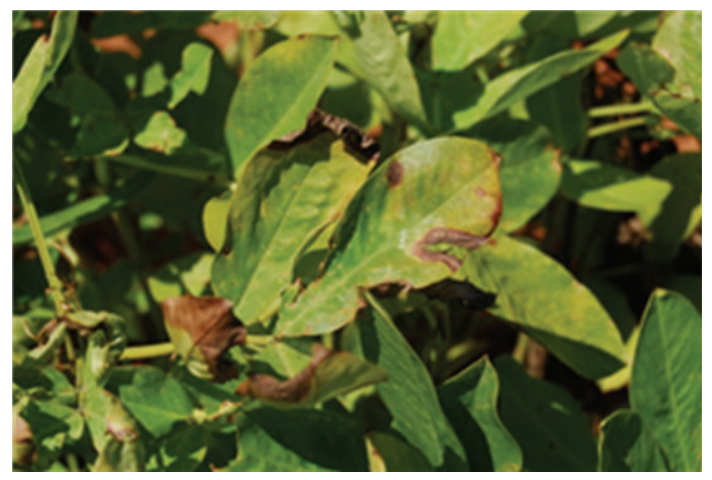

(a)

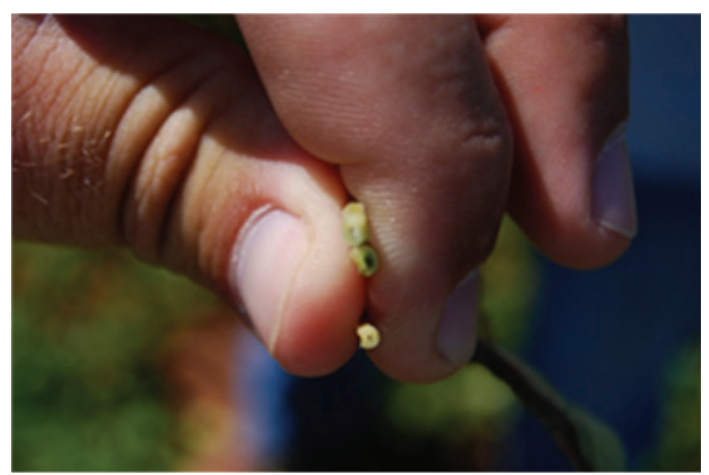

(b)

FIGURE 13: Chlorosis, necrosis, and wilting of leaves (a) and vascular discoloration (b) caused by Verticillium dahliae.

host resistance, irrigation regimes, crop rotation, and soil fertility may also affect disease incidence.

8.1. Host Resistance. Utilizing host resistance plays an important role in disease management because of the ongoing loss of chemical use due to pathogen resistance and government restrictions placed on various agronomic chemicals. Host resistance is also the least expensive, safest, and most effective method to manage plant disease.

Until recently, host resistance to Sclerotium rolfsii was unavailable; however, tolerance to $S$. rolfsii may aid in management in conjunction with other control methods
[19]. Peanut plants with upright growth habits or with compact or open canopies show less disease than those with a more humid microclimate or more leaves in contact with the soil [18]. Cultivars such as Southern Runner and Georgia Browne show less disease than Florunner [17]. Several partially resistant cultivars are available such as UFMDR-98, C-99R, Georgia-07W, Georgia-03L, Georgia-02C, DP-1, and AP-3 [23-28].

Pod rot control through host resistance may be effective, but is dependent on the identification of the causal agent. Spanish cultivars, especially Toalson, may provide resistance to both Pythium spp. and $R$. solani $[7,10]$. Partial resistance to $R$. solani has also been identified in the runner peanut Georgia Browne. Resistance to Sclerotinia blight has been shown in the varieties Virginia 81B, Virginia 93B, Tamspan90, and Southwest Runner [13], and more recently Tamrun OL07 [29].

Currently, limited information is available for resistance of peanut to Verticillium wilt. In a recent study, the commercial standard, Flavor Runner 458, performed well in fields with a history of Verticillium wilt [30]. Employing phenological suppression may also be a viable option when selecting peanut cultivars due to the lack of resistance against various pathogens [18]. Planting cultivars with an upright growth habit may limit contact of the canopy with the soil, reducing disease incidence [17].

8.2. Irrigation. Maintaining adequate moisture without overwatering peanuts may limit disease incidence by various soilborne pathogens; however, drastic reductions in irrigation can limit yield potential. The dense canopy produced by peanut imposes a microclimate with increased humidity that may influence disease incidence. Since Pythium spp. produces motile zoospores that travel in water, overwatering and flooding should be avoided.

8.3. Crop Rotation. Crop rotation is a deliberate order of crops planted in the same field over several seasons. In the West Texas region of the Southern High Plains, peanut is rotated with cotton (Gossypium). Several benefits exist from crop rotations, including limiting the buildup of fungal inoculum, weed control, and promoting good soil fertility $[31,32]$.

Unfortunately, cotton and peanut share many pathogens, such as V. dahliae, Pythium spp., and R. solani. Rotating peanut with grass species such as corn, grain sorghum, or other pasture grasses may reduce both $R$. solani $[10,33]$ and $S$. rolfsii [17]. Verticillium dahliae has an extended longevity in the soil as microsclerotia, and their levels are not dramatically affected by short-term crop rotations. Crop rotation has been shown to reduce the inoculum density of Pythium spp., but has little effect on disease incidence [7].

8.4. Soil Fertility. Soil fertility refers to the nutrient availability in a soil, and the fertility of a soil may be affected by crop rotations, soil $\mathrm{pH}$, and soil moisture levels. Improving soil fertility may directly affect pathogens, improve plant health by limiting its susceptibility, or increase antagonistic microbial growth. Soil nutrients such as nitrogen and 
calcium may also influence the incidence and severity of infections caused by soilborne fungi.

Nitrogen availability is incredibly important for plant health. Nitrogen applications, as ammonium, may directly inhibit the germination and limit the mycelial growth of $S$. rolfsii [19]. Nitrogen amendments with nitrogenous compounds or plant residues may also lead to the fortification of antagonistic microbes, such as Trichoderma spp., Gliocladium spp., and Penicillium spp. [13], or may cause death of sclerotia [19]. While nitrogen may improve plant health, an overabundance of nitrogen may cause an increase in disease, such as Rhizoctonia pod rot or Verticillium wilt. Increases in Rhizoctonia pod rot may be due to the stimulatory effect of nitrogen on $R$. solani. This may be due to increased root volume that increases the contact with soilborne pathogens [19].

Calcium levels may also affect disease incidence by improving cell wall composition, making them more resistant to pathogen penetration [34]. Under low disease pressure by S. rolfsii, increased calcium levels in peanut tissue may limit disease development [19]. Calcium also may be used in the prevention of pod rot disease caused by Pythium spp. and R. solani $[7,10,35]$. Calcium amendments have been shown to lessen disease incidence and severity [36]; however, the West Texas region of the southern high plains continues to see pod rot incidence despite high calcium levels in the soil, which may be attributed to the inoculum potential of soil or calcium retention potential in soils [37].

\section{Chemical Management of Soilborne Diseases}

9.1. Fungicides. For the management of soilborne fungal pathogens, a combined management strategy utilizing both cultural management practices and chemical control practices is important. Protectant fungicide applications prior to infection and curative fungicide applications just after infections occur are effective in reducing losses. Many fungicides have broad spectrum activity and are capable of control of various fungal classes. The strobilurins, which are beta-methoxy acrylic acid derivatives, have broad-spectrum activity and show activity against various foliar and soilborne pathogens [38]. Strobilurins, such as azoxystrobin, inhibit electron transport by binding to the QoI site of Cytochrome b [38]. Triazole fungicides, such as propiconazole and tebuconazole, also have a broad spectrum of activity that inhibits sterol demethylation $[11,39]$. Phenylamides, such as metalaxyl, inhibit nucleic acid synthesis by affecting RNA synthesis via RNA polymerase I [40]. The fungicide flutolanil prevents respiration by inhibiting succinate dehydrogenase synthesis [40]. Aromatic hydrocarbon fungicides, such as pentachloronitrobenzene (PCNB), cause lipid peroxidation, which leads to the loss of integrity of the cell membrane [41]. Fluazinam, a pyridinamine fungicide, is a broad-spectrum fungicide with multisite activity that inhibits the respiration of fungi [42].

Peanut producers have various fungicides to choose from to manage peanut diseases. Multiaction protectant fungicides, such as chlorothalonil, are effective against foliar diseases, but are ineffective against most all soilborne pathogens [5]. Broad-spectrum fungicides also alleviate losses to disease, and control a wide range of pathogens. Tebuconazole is a broad-spectrum, systemic fungicide, that may be used to manage soilborne Basidiomycetes such as $R$. solani and S. rolfsii [10, 11, 17, 39]. Azoxystrobin, another broad spectrum fungicide may also be used to control soilborne Basidiomycetes and has limited activity on Pythium spp. [43]. Flutolanil, a systemic, curative fungicide, is used to control basidiomycetes such as $S$. rolfsii and $R$. solani, and is especially effective at controlling mycelia growth and infection cushion formation [44, 45]. Boscalid is another fungicide that has activity against leaf spot, Sclerotinia blight, and Southern blight in peanut [46]. Metalaxyl and mefenoxam may provide control over oomycetes, such as Pythium spp. $[8,37]$. Iprodione inhibits the germination of spores and limits the fungal growth of $B$. cinerea and $S$. minor and S. sclerotiorum [47]. Fluazinam has also been used to manage the Sclerotinia blight in peanut [16].

9.2. Fungicide Timing. Current spray regimes are targeted to reduce yield losses. Optimizing initial fungicide application timing is important in reducing yield losses to disease as well as minimizing the costs of utilizing fungicides. In general, fungicide regimes and initial fungicide applications are based on the Southern blight disease model in the southeastern United States, and initial applications are typically 60 days after planting (DAP). Following the initial application, subsequent applications targeting soilborne pathogens are made between 90 and 120 DAP $[47,48]$.

The residual activity of fungicides also affects disease development. In a study by Csinos, the residual activity of flutolanil at pegging or pod development provided greater disease control than applications at planting [44]. Azoxystrobin and tebuconazole also display activity against $R$. solan $i$ [44]. The number of applications applied may impact the disease development caused by soilborne pathogens. In a study by Bowen et al., the number of spray applications was evaluated, and four applications in the growing season provided the greatest control [49]. Economic constraints, however, may limit the timing and number of applications of azoxystrobin or tebuconazole a grower may apply [43, 49].

Producers in the Southern High Plains make fewer applications of fungicides than those in the southeastern United States. Applying fungicides too early may force producers to add a third application at the end of the growing season. Delaying initial applications of fungicides may provide peanuts with greater protection at the end of the growing season, but may not provide protection from infection early in the season. Peanuts in the Southern High Plains develop later than those grown in southeast portion of the United States, and a reevaluation of fungicide application timing may be necessary.

\section{References}

[1] D. M. Porter, "The peanut plant," in Compendium of Peanut Diseases, N. Kokalis-Burelle, D. M. Porter, R. RodriguezKabana, D. H. Smith, and P. Subrahmanyam, Eds., pp. 1-2, APS Press, St. Paul, Minn, USA, 2nd edition, 1997. 
[2] B. W. Smith, "Arachis hypogaea. Aerial flower and subterranean fruit," American Journal of Botany, vol. 37, pp. 802-815, 1950.

[3] T. A. Coffelt and C. E. Simpson, "Origin of the peanut," in Compendium of Peanut Diseases, N. Kokalis-Burelle, D. M. Porter, R. Rodriguez-Kabana, D. H. Smith, and P. Subrahmanyam, Eds., p. 2, APS Press, St. Paul, Minn, USA, 2nd edition, 1997.

[4] Texas Peanut Producers Board, "Peanut Production," 2011, http://www.texaspeanutboard.com/industry-production. html.

[5] D. M. Porter, "Botrytis blight," in Compendium of Peanut Diseases, N. Kokalis-Burelle, D. M. Porter, R. RodriguezKabana, D. H. Smith, and P. Subrahmanyam, Eds., pp. 10-11, APS Press, St. Paul, Minn, USA, 2nd edition, 1997.

[6] T. A. Wheeler, C. R. Howell, J. Cotton, and D. Porter, "Pythium species associated with pod rot on west texas peanuts and in vitro sensitivity of isolates to mefenoxam and azoxystrobin," Peanut Science, vol. 32, pp. 9-13, 2005.

[7] M. K. Beute, "Pythium diseases," in Compendium of Peanut Diseases, N. Kokalis-Burelle, D. M. Porter, R. RodriguezKabana, D. H. Smith, and P. Subrahmanyam, Eds., pp. 27-30, APS Press, St. Paul, Minn, USA, 2nd edition, 1997.

[8] P. I. Lewis and A. B. Filonow, "Reaction of peanut cultivars to Pythium pod rot and their influence on populations of Pythium spp. in soil," Peanut Science, vol. 17, pp. 90-95, 1990.

[9] J. C. Wells and P. M. Phipps, "Peanut disease guide North Carolina and virginia," Center for Integrated Pest Management, 1997, http://ipm.ncsu.edu/peanuts/diseases/guide/ contents.html.

[10] T. B. Brenneman, "Rhizoctonia diseases," in Compendium of Peanut Diseases, N. Kokalis-Burelle, D. M. Porter, R. Rodriguez-Kabana, D. H. Smith, and P. Subrahmanyam, Eds., pp. 30-31, APS Press, St. Paul, Minn, USA, 2nd edition, 1997.

[11] T. B. Brenneman, H. R. Sumner, L. R. Chandler, J. M. Hammond, and A. K. Culbreath, "Effect of application techniques on performance of propiconazole for peanut disease control," Peanut Science, vol. 21, pp. 134-138, 1994.

[12] J. P. Damicone and H. A. Melouk, "Soilborne diseases of peanut," Tech. Rep. EPP-7664, Oklahoma Cooperative Extension Service, 2009.

[13] D. M. Porter and H. A. Melouk, " Sclerotinia blight," in Compendium of Peanut Diseases, N. Kokalis-Burelle, D. M. Porter, R. Rodriguez-Kabana, D. H. Smith, and P. Subrahmanyam, Eds., pp. 34-36, APS Press, St. Paul, Minn, USA, 2nd edition, 1997.

[14] J. E. Woodward, T. B. Brenneman, R. C. Kemerait, A. K. Culbreath, and J. R. Clark, "First report of Sclerotinia blight caused by Sclerotinia sclerotiorium on peanut in Georgia," Plant Disease, vol. 90, article 111, 2006.

[15] J. E. Woodward and T. B. Brenneman, "Development of an inoculation method for quantifying fungicide residues on peanut foliage," Peanut Science, vol. 35, pp. 25-31, 2008.

[16] T. M. Butzler, J. Bailey, and M. K. Beute, "Integrated management of Sclerotinia blight in peanut: utilizing canopy morphology, mechanical pruning, and fungicide timing," Plant Disease, vol. 82, no. 12, pp. 1312-1318, 1998.

[17] P. A. Backman and T. B. Brenneman, "Stem rot," in Compendium of Peanut Diseases, N. Kokalis-Burelle, D. M. Porter, R. Rodriguez-Kabana, D. H. Smith, and P. Subrahmanyam, Eds., pp. 36-37, APS Press, St. Paul, Minn, USA, 2nd edition, 1997.

[18] B. B. Shew, J. C. Wynne, and M. K. Beute, "Field, microplot, and greenhouse evaluations of resistance to Sclerotium rolfsii in peanut," Plant Disease, vol. 71, pp. 188-191, 1987.
[19] Z. K. Punja, "The biology, ecology, and control of Sclerotium rolfsii," Annual Review of Phytopathology, vol. 23, pp. 97-127, 1985.

[20] J. Mullen, "Southern blight, Southern stem blight, White mold. The Plant Health Instructor," 2001, http://www.apsnet. org/edcenter/intropp/lessons/fungi/Basidiomycetes/Pages/ SouthernBlight.aspx.

[21] H. A. Melouk and J. P. Damicone, "Verticillium wilt," in Compendium of Peanut Diseases, N. Kokalis-Burelle, D. M. Porter, R. Rodriguez-Kabana, D. H. Smith, and P. Subrahmanyam, Eds., pp. 37-38, APS Press, St. Paul, Minn, USA, 2nd edition, 1997.

[22] L. J. Ashworth Jr., O. C. Huisman, D. M. Harper, L. K. Stromberg, and D. M. Bassett, "Verticillium wilt disease of cotton: influence of inoculum density in the field," Phytopathology, vol. 69, pp. 483-489, 1979.

[23] D. W. Gorbet and F. M. Shokes, "Registration of "C-99R" peanut," Crop Science, vol. 42, article 2207, 2002.

[24] D. W. Gorbet and F. M. Shokes, "Registration of "MDR-98" peanut," Crop Science, vol. 42, pp. 2207-2208, 2002.

[25] W. D. Branch and T. B. Brenneman, "Field evaluation for the combination of white mould and tomato spotted wilt disease resistance among peanut genotypes," Crop Protection, vol. 28, no. 7, pp. 595-598, 2009.

[26] W. D. Branch, "Registration of "Georgia-02C" peanut," Crop Science, vol. 43, pp. 1883-1884, 2003.

[27] T. B. Brenneman, A. K. Culbreath, and C. C. Holbrook, "Screening cultivars and advanced germplasm for multiple disease resistance," Proceedings of the American Peanut Research and Education Society, vol. 37, article 30, 2005.

[28] D. W. Gorbet, T. A. Kucharek, F. M. Shokes, and T. B. Brenneman, "Field evaluations of peanut germplasm for resistance to stem rot caused by Sclerotium rolfsii," Peanut Science, vol. 31, pp. 91-95, 2004.

[29] M. R. Baring, C. E. Simpson, M. D. Burow et al., "Registration of "Tamrun OL07” Peanut," Crop Science, vol. 46, pp. 27212722, 2006.

[30] J. E. Woodward, T. A. Baughman, and T. A. Wheeler, "Strategies for Managing Verticillium Wilt in Peanut," Texas Agrilife Extension Publication, 2011, http://gaines.agrilife. org/files/2011/09/Strategies-for-Managing-Verticillium-wiltin-Peanut_14.pdf.

[31] R. D. Peters, A. V. Sturz, M. R. Carter, and J. B. Sanderson, "Developing disease-suppressive soils through crop rotation and tillage management practices," Soil and Tillage Research, vol. 72, no. 2, pp. 181-192, 2003.

[32] M. Liebman and E. Dyck, "Crop rotation and intercropping strategies for weed management," Ecological Applications, vol. 3, no. 1, pp. 92-122, 1993.

[33] R. E. Baird, T. B. Brenneman, D. K. Bell et al., "Influence of crop rotation and flutolanil on the diversity of fungi on peanut shells," Phytoprotection, vol. 76, pp. 101-113, 1995.

[34] G. N. Agrios, "Effect of host-plant nutrition," in Plant Pathology, pp. 257-262, Elsevier Academic Press, Burlington, Mass, USA, 5th edition, 2005.

[35] M. E. Walker and A. S. Csinos, "Effect of gypsum on yield, grade and incidence of pod rot in five peanut cultivars," Peanut Science, vol. 7, pp. 109-113, 1980.

[36] A. S. Csinos, "Evaluation of the insecticide chlorpyrifos for activity against southern stem rot on peanuts," Peanut Science, vol. 11, pp. 98-102, 1984.

[37] A. B. Filonow and K. E. Jackson, "Effect of metalaxyl plus PCNB or metalaxyl plus tolclofos-methyl on peanut pod rot 
and soil populations of Pythium spp. and Rhizoctonia solani," Peanut Science, vol. 16, pp. 25-32, 1989.

[38] D. W. Bartlett, J. M. Clough, J. R. Godwin, A. A. Hall, M. Hamer, and B. Parr-Dobrzanski, "The strobilurin fungicides," Pest Management Science, vol. 58, no. 7, pp. 649-662, 2002.

[39] R. E. Baird, T. B. Brenneman, D. K. Bell, and A. P. Murphy, "The effects of the fungicide propiconazole (Tilt) on the groundnut shell mycobiota," Mycological Research, vol. 95, pp. 571-576, 1991.

[40] Fungicide Resistance Action Committee, "FRAC Mode of Action of Fungicides: FRAC Classification on Mode of Action 2007. CropLife International," 2007, http://www.frac.info/ frac/publication/anhang/FRAC_MoA_Poster_2007.pdf.

[41] M. Y. Shim, J. L. Starr, N. P. Keller, K. E. Woodard, and T. A. Lee Jr., "Distribution of isolates of Sclerotium rolfsii tolerant to pentachloronitrobenzene in Texas peanut fields," Plant Disease, vol. 82, no. 1, pp. 103-106, 1998.

[42] Syngenta, "Omega fungicide," 2012, http://www.syngentacropprotection.com/prodrender/index.aspx?prodid $=632$.

[43] W. J. Grichar, B. A. Besler, and A. J. Jaks, "Use of azoxystrobin for disease control in Texas peanut," Peanut Science, vol. 27, pp. 83-87, 2000.

[44] A. S. Csinos, "Control of southern stem rot and Rhizoctonia limb rot of peanut with flutolanil," Peanut Science, vol. 14, pp. 55-58, 1987.

[45] W. J. Grichar, "Management of stem rot of peanuts (Arachis hypogaea) caused by Sclerotium rolfsii with fungicides," Crop Protection, vol. 14, no. 2, pp. 111-115, 1995.

[46] BASF, "Endura fungicide," 2012, http://agproducts.basf.us/ products/endura-fungicide.html.

[47] D. B. Langston Jr., P. M. Phipps, and R. J. Stipes, "An algorithm for predicting outbreaks of Sclerotinia blight of peanut and improving the timing of fungicide sprays," Plant Disease, vol. 86, no. 2, pp. 118-126, 2002.

[48] S. L. Rideout, T. B. Brenneman, A. K. Culbreath, and D. B. Langston Jr., "Evaluation of weather-based spray advisories for improved control of peanut stem rot," Plant Disease, vol. 92, no. 3, pp. 392-400, 2008.

[49] L. Bowen, A. K. Hagan, and J. R. Weeks, "Number of tebuconazole applications for maximizing disease control and yield of peanut in growers' fields in Alabama," Plant Disease, vol. 81, no. 8, pp. 927-931, 1997. 


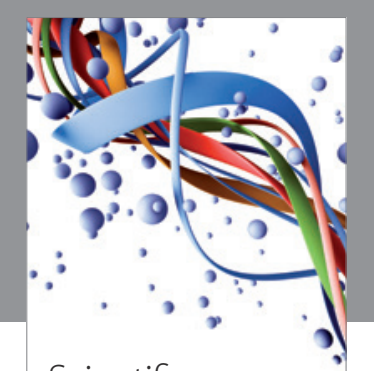

Scientifica
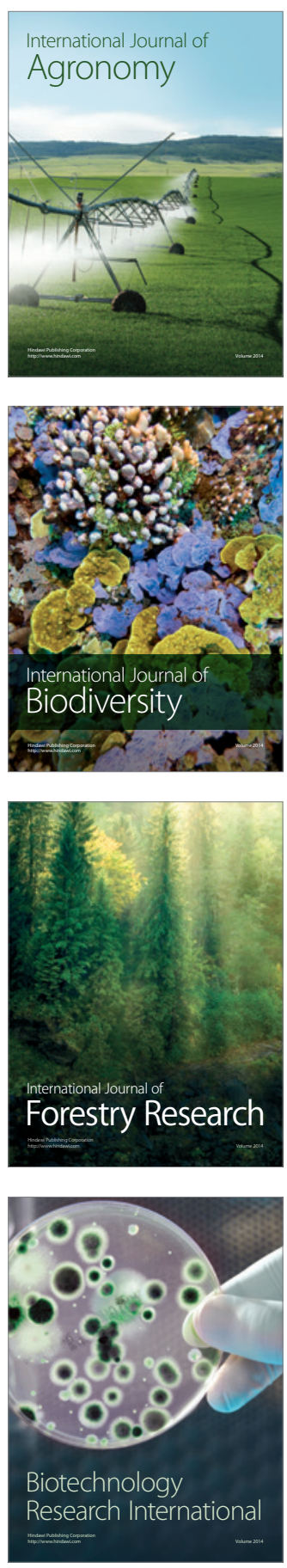
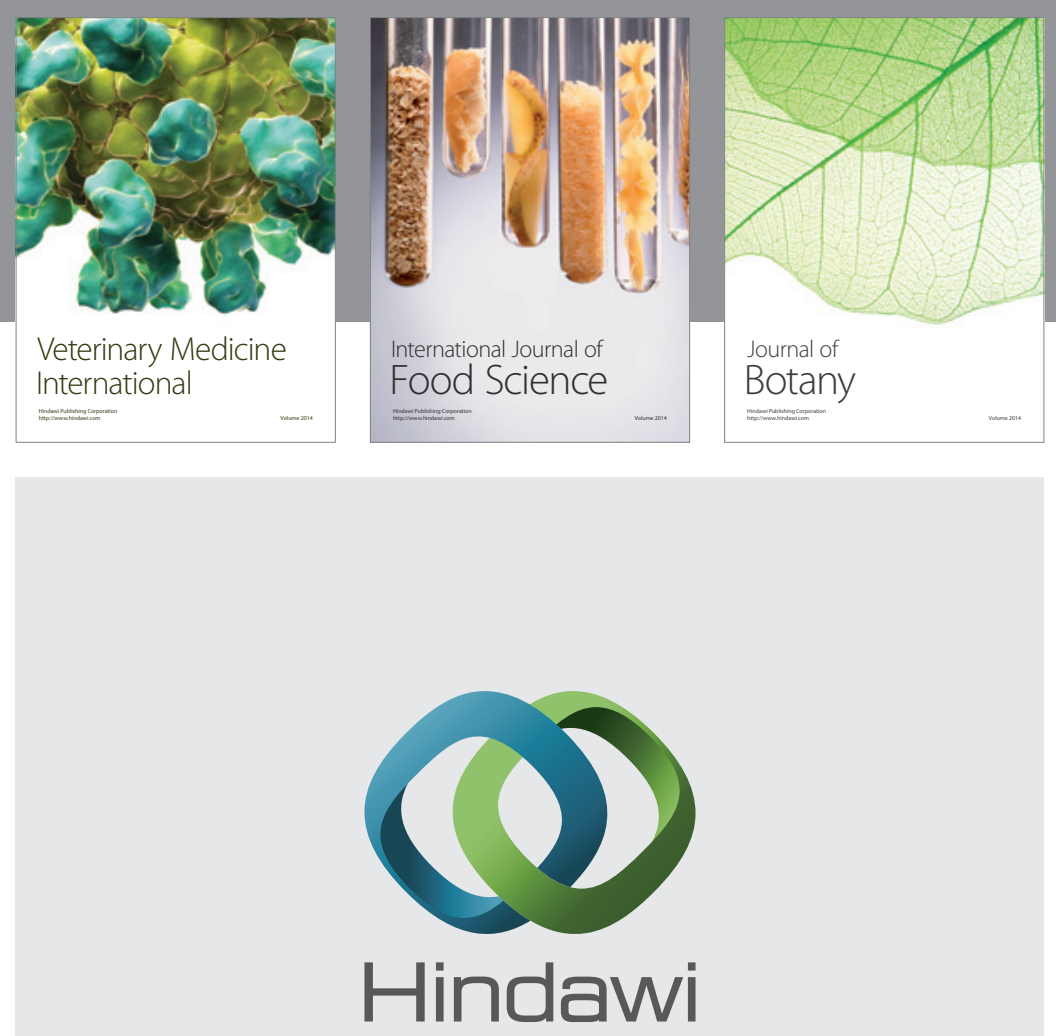

Submit your manuscripts at

http://www.hindawi.com
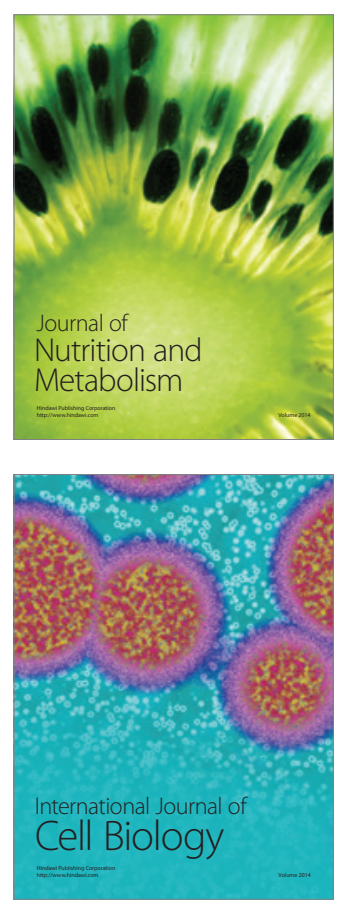
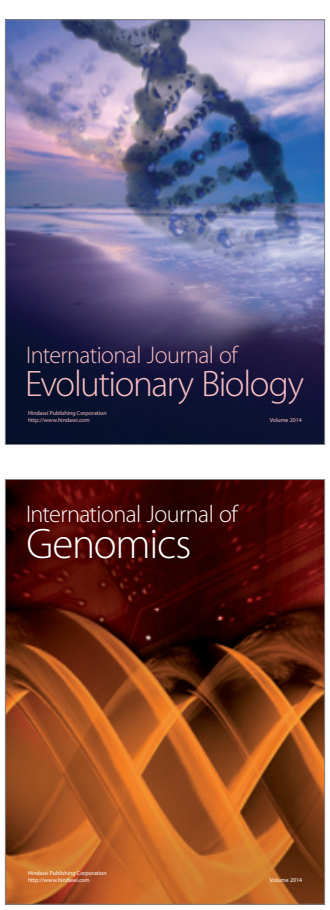
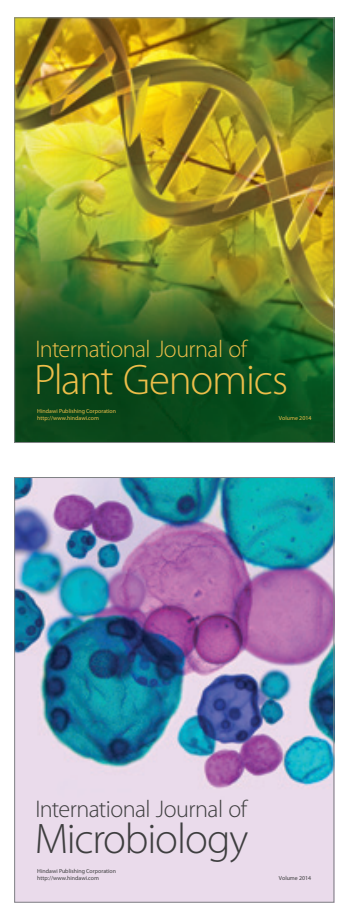

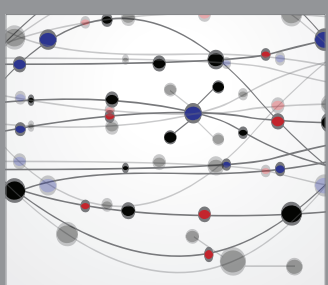

The Scientific World Journal
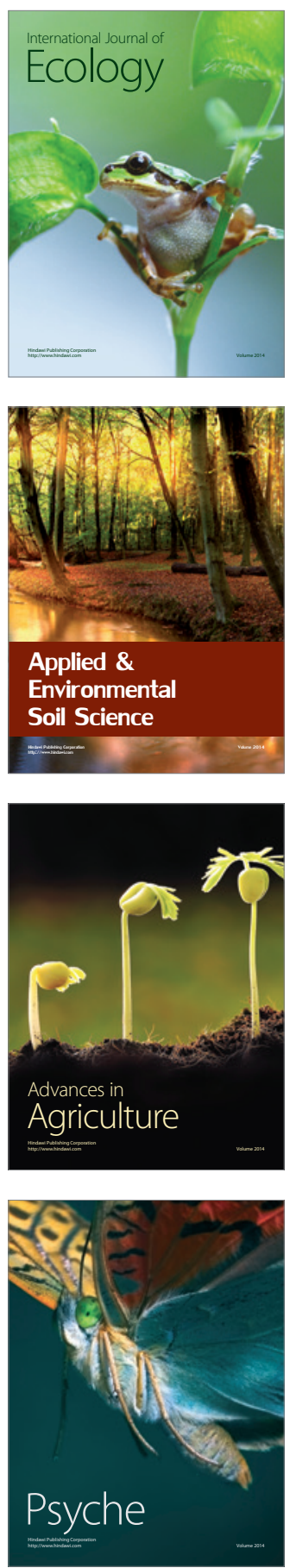